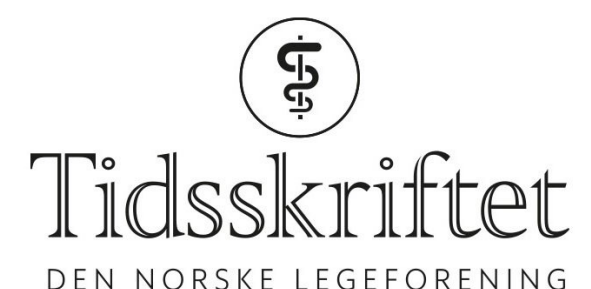

DEN NORSKE LEGEFORENING

\title{
Helge Riisøen
}

MINNEORD

OLE-BJØRN TYSNES

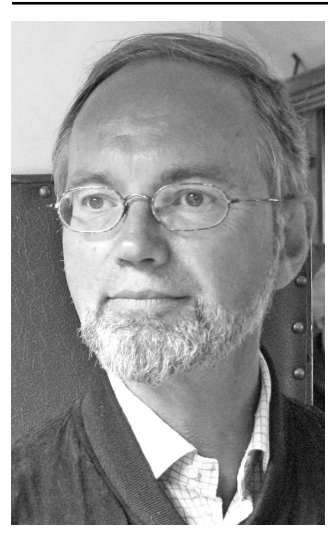

Spesialist i nevrologi og overlege Helge Gjessing Uchermann Riisøen døde 7. mai 2019, 67 år gammel. Helge var utdannet ved Det medisinske fakultet i Bergen og gjennomførte spesialistutdanning i nevrologi ved Haukeland universitetssjukehus. Han arbeidet hele sitt yrkesaktive liv ved Nevrologisk avdeling inntil han på grunn av kronisk sykdom måtte pensjonere seg for 3 år siden.

Helge Riisøen hadde suksess som forfatter da han som nyutdannet lege skrev kriminalromaner fra sykehusmiljøet på Haukeland. Bøkene fikk svært gode kritikker, og Helge mottok den prestisjetunge Rivertonprisen i 1979. Hans karriere som kriminalforfatter ble lagt på is da han startet arbeidet i Nevrologisk avdeling, men hans interesse for språk, bøker og historie opptok ham hele livet. Hans beskrivelse av hverdagslige og trivielle forhold i avdelingen kunne svært ofte ha lyrisk karakter, slik at han ofte var et muntrasjonsråd for kolleger og andre ansatte.

Helge Riisøen tok svært tidlig i bruk ultralyd/dopplerteknikk for å fremstille blodsirkulasjonen til hjernen. Han arbeidet raskt og effektivt, og det ble etter hvert naturlig for ham å ha sin hovedaktivitet knyttet til nevrologisk poliklinikk. Kompetansen på cerebrovaskulære sykdommer benyttet han gjennom hele sitt yrkesliv.

Helge Riisøen var et ja-menneske. Det var alltid mulig å spørre ham om å ta på seg ekstraoppgaver. Til tross for at han hadde det travelt, var han alltid vennlig og imøtekommende. Han ble som følge av denne holdningen høyt verdsatt av leger, sykepleiere og merkantilt ansatte. Helge hadde utenfor avdelingen i en årrekke funksjon som «lege for leger», hvor leger kunne henvendte seg til ham med helseproblemer. Som nevrolog var Helge naturlig opptatt av arvelige sykdommer. Dette, sammen med historisk interesse, gjorde at han fordypet seg og foreleste om mørke sider i samfunnet, hvor en i tidligere år har forsøkt å utrydde mennesker med kroniske sykdommer i nervesystemet. 
Han viste oss at det er viktig å holde kunnskap om vår nære historie oppdatert for å unngå overgrep som ikke var uvanlige i mellomkrigstiden, også i Norge.

Vi minnes Helge Riisøen som en kunnskapsrik kliniker med empati for sine pasienter og med omsorg for kolleger. Dessverre utviklet han i altfor ung alder kronisk sykdom som førte til at han måtte slutte i arbeid og som er årsaken til at han nå er gått bort.

På vegne av alle kolleger $i$ Nevrologisk avdeling

Publisert: 9. september 2019. Tidsskr Nor Legeforen. DOI: 10.4045/tidsskr.19.0464

(C) Tidsskrift for Den norske legeforening 2020. Lastet ned fra tidsskriftet.no 